\title{
Maxillary Sinus Cancer cM0 TNM Finding v7
}

National Cancer Institute

\section{Source}

National Cancer Institute. Maxillary Sinus Cancer cMO TNM Finding v7. NCI Thesaurus.

Code C89103.

Maxillary sinus cancer without evidence of distant metastasis. (from AJCC 7th Ed.) 